\title{
The Early Developmental Stages of Psychopathology Study (EDSP): A Methodological Update
}

\author{
Roselind Lieb Barbara Isensee Kirsten von Sydow Hans-Ulrich Wittchen \\ Clinical Psychology and Epidemiology Unit, Max Planck Institute of Psychiatry, Munich, Germany
}

\section{Key Words}

Epidemiology · Prospective longitudinal design .

Community study · Substance use disorders · Family history $\cdot$ Adolescents

\begin{abstract}
The objectives of the community-based Early Developmental Stages of Psychopathology (EDSP) Study are described along with a detailed account of the overall design, special design features, sample characteristics and instruments used. The EDSP employed a prospective-longitudinal design to study substance use and other mental disorders in a representative population sample of 3,021 subjects aged 14-24 years (birth cohorts 1970-1981) at 'baseline' - the outset of the study. Two follow-up investigations were conducted after the baseline investigation covering an overall period of 3-4 years. Special design features are the linkage with a family supplement (EDSP-FS) as well as neurobiological laboratory studies of high-risk subjects.
\end{abstract}

Copyright $(2000$ S. Karger AG, Basel

\section{Background of the EDSP}

In 1994, the German government launched the 'Biological and Psychosocial Factors of Drug Abuse' program coordinated by the Ministry of Research and Technology in order to improve the overall knowledge about substance use disorders. Within this program five epidemiological projects were funded, linked together in a collaborative network named ANEPSA (Analytical Epidemiology of Psychoactive Substance Abuse). Aims of the network are to cooperate in the research on the longitudinal course of substance use, abuse and dependence and in the analyses of factors related to the onset and change of substance use patterns. Methods, design and first findings of the ANEPSA projects have been published in several journals and books [1-14]. As one of the epidemiological core projects, the Early Developmental Stages of Psychopathology (EDSP) Study was carried out at the Max Planck Institute of Psychiatry in Munich, Unit for Clinical Psychology and Epidemiology. The EDSP employed a prospective-longitudinal design to study pathways into substance use, abuse and dependence in a representative population sample of 3,021 subjects initially aged 14-24 years, including a baseline and two follow-up assessments

Dr. Roselind Lieb

Max Planck Institute of Psychiatry

Clinical Psychology and Epidemiology Unit, Kraepelinstrasse 2

D-80804 München (Germany)

Tel. +49 8930622 241, Fax +49 8930622 544, E-Mail lieb@mpipsykl.mpg.de
Fax + 41613061234 E-Mail karger@karger.ch www. karger.com 


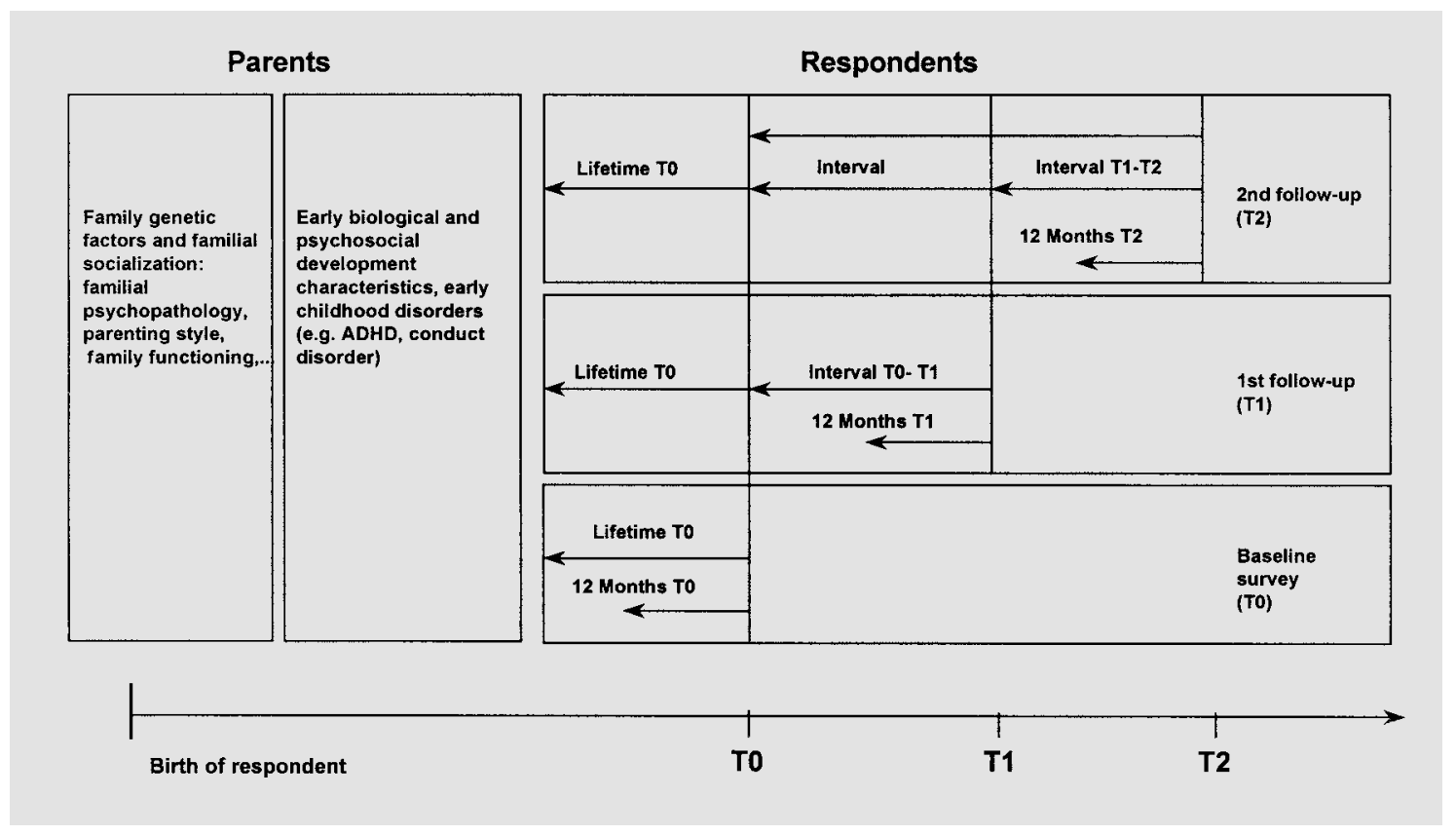

Fig. 1. EDSP design.

and an independent parent investigation. In a special issue of European Addiction Research and several further publications, the objectives, basic design, description of the baseline investigation and selected baseline findings have already been published [15-22, see also ref. 23-25]. Further publications that included first longitudinal findings referring to baseline and first follow-up have been presented [26-29]. Meanwhile the third and final wave of the prospective-longitudinal EDSP has been completed successfully and with this paper we will take the opportunity to provide an overview over the whole EDSP study and its methodology including all three assessment waves as well as the independent parent study.

\section{Study Objectives}

As the objectives of the EDSP have been presented already in detail [16], only the general goals are briefly highlighted here. The primary goal of the study is to provide prevalence and incidence estimates of substance use, abuse and dependence among adolescents and young adults. Secondly, the EDSP aims to study the natural course of early stages of substance use and substance use disorders (e.g. initiation of use, progression to abuse) over a period of several years and to identify risk factors that are associated with changes from one stage to another. Further main goals of the EDSP include the examination of comorbidity of substance use disorders with each other, as well as with other mental disorders, and the investigation of familial vulnerability factors and mechanisms that may be involved in the onset and course of substance use disorders.

\section{Design}

The overall design of the EDSP is a prospective-longitudinal design based on a representative community sample of adolescents and young adults living in the Munich area, aged 14-24 years at baseline. The age range for the targeted population was chosen to address especially the early developmental stages of substance use, abuse and dependence and other mental disorders. The EDSP consists of a baseline investigation (T0), two follow-up investigations (T1, T2) and an independent parent survey. Because of the focus on early developmental stages of psychopathology and substance use, only the younger cohort of adolescents, aged 14-17 years at baseline, was examined in the first follow-up investigation. In the final follow-up investigation, the entire baseline sample was assessed again. 
A key design feature of the EDSP is a special family supplement (EDSP-FS) to investigate the familial contributions to the development of substance use and other mental disorders. In order to identify familial vulnerability factors and mechanisms involved in the onset and course of mental disorders, baseline and follow-up investigations included a family history module to gather information about substance use and mental disorders in respondents' parents and siblings. Separate face-to-face interviews were conducted with the parents of the respondents of the first follow-up in order to gather more comprehensive direct information than at baseline about family genetic variables. In addition, information for childhood development and childhood disorders was collected as part of these parent interviews.

Figure 1 summarizes the overall design of the EDSP. On the left side, the two columns represent family genetic and familial socialization factors as well as early biological and psychosocial characteristics assessed in the direct parent interviews. On the right side, the three waves of interviews with our sample aged 14-24 at the outset of the study are shown, providing information about their use of all legal and illegal psychotropic substances on the level of use, pattern of use, symptoms and diagnosis. The reference periods of assesssment include lifetime and 12month time frames; furthermore due to variable time distances of interviews between waves 1 and 2 as well as 2 and 3 special attempts were made to collect information on the time intervals beyond 12 months.

\section{Sample}

\section{Sampling of the Respondents and Baseline}

\section{Investigation}

The EDSP sample was drawn randomly from the 1994 government population registers of residents in metropolitan Munich and its surroundings with an expected age range for the sampled subjects between 14 and 24 years (birth cohorts 1970-1981) at the time of the baseline interview in 1995. As the study is designed with special interest in early stages of substance use disorders, 14- to 15 -year-olds were sampled at twice the probability of persons 16-21 years of age, and 22- to 24-year-olds were sampled at half this probability. A total of 3,021 interviews were completed at baseline, resulting in a response rate of $71 \%$. Detailed descriptions of the sampling procedures of the baseline investigation and reasons for nonresponse have already been presented elsewhere $[8,16]$.
Table 1. Response rates in the second follow-up investigation (by sex and age groups)

\begin{tabular}{|c|c|c|c|c|}
\hline & \multicolumn{2}{|c|}{ Baseline sample (T0) } & \multicolumn{2}{|c|}{$\begin{array}{l}\text { Response rates in } \\
\text { second follow-up (T2) }\end{array}$} \\
\hline & $\mathrm{n}$ & $\%$ & $\mathrm{n}$ & $\% \mathrm{~T} 0^{1}$ \\
\hline Total & 3,021 & 100 & 2,548 & 84.3 \\
\hline \multicolumn{5}{|l|}{ Men } \\
\hline Total & 1,533 & 50.7 & 1,297 & 84.6 \\
\hline $14-15$ years & 470 & 15.6 & 400 & 85.1 \\
\hline $16-17$ years & 244 & 8.1 & 203 & 83.2 \\
\hline $18-19$ years & 241 & 8.0 & 202 & 83.8 \\
\hline $20-21$ years & 243 & 8.0 & 206 & 84.8 \\
\hline $22-24$ years & 335 & 11.1 & 286 & 85.4 \\
\hline \multicolumn{5}{|l|}{ Women } \\
\hline Total & 1,488 & 49.3 & 1,251 & 84.1 \\
\hline $14-15$ years & 433 & 14.3 & 362 & 83.6 \\
\hline $16-17$ years & 248 & 8.2 & 204 & 82.3 \\
\hline $18-19$ years & 219 & 7.2 & 190 & 86.8 \\
\hline $20-21$ years & 255 & 8.4 & 214 & 83.9 \\
\hline $22-24$ years & 333 & 11.0 & 281 & 84.4 \\
\hline
\end{tabular}

Percentage of baseline sample $(\mathrm{T} 0 ; \mathrm{n}=3,021)$

\section{First and Second Follow-Ups}

Two follow-up investigations were completed after the baseline investigation, covering an overall period of 3-4 years. Due to the large number of respondents, it was technically not feasible to keep a constant time interval between the different waves. The first follow-up was conducted in 1996/1997, an average of 19.7 months after baseline (range: 14-25 months). This wave included only the respondents who were 14-17 years old at baseline $(\mathrm{n}=$ 1,395; birth cohorts 1977-1981). Of the baseline 14- to 17-year-old respondents, 1,228 participated in the first follow-up investigation, resulting in a response rate of $88 \%$. The most frequent reasons for nonresponse were refusal to participate $(6.4 \%)$, lack of time $(1.5 \%)$ and failure to contact the individual (1.5\%).

The second follow-up investigation included all baseline respondents and was conducted in 1998/1999, an average of 42 months after the baseline investigation (range: 34-50 months). Of the 3,021 baseline respondents, 2,548 participated again in the second follow-up investigation, resulting in a response rate of $84 \%$. Again, the most frequent reasons for nonresponse were refusal to participate $(9.2 \%)$, failure to contact the individual $(2.7 \%)$ and lack of time (1.5\%). Table 1 shows the response rates in the second follow-up by sex and age groups. 


\section{Sociodemographic Characteristics}

Table 2 shows the distribution of some sociodemographic variables in the sample at baseline and second follow-up for the total group and by gender. At baseline, $36.2 \%$ of the respondents were in secondary school. Most (24.0\%) attended 'Gymnasium' (secondary education between ages of 10 and 19 that prepares students for entrance to university), 9.3\% attended a more basic or intermediate level of school ('Hauptschule', a mandatory basic school, or 'Realschule', an intermediate type of advanced school between Hauptschule and Gymnasium). $26.4 \%$ of the respondents attended university, $10.5 \%$ were in job training and $19.7 \%$ were employed. The majority of respondents $(62.4 \%)$ were living with their parents, and only a few (3.4\%) were married. The vast majority of respondents were classified as (upper) middle class $(87.4 \%)$, which is consistent with the demographics of the Munich population. Only $7.6 \%$ reported lower social class status.

At the time of the second follow-up investigation, a considerably lower proportion of respondents $(12.8 \%)$ was still attending a school other than university, while more respondents $(36.2 \%)$ were employed. A lower proportion of respondents $(40.2 \%)$ still lived with their parents, while more subjects lived with a partner $(22.7 \%)$ or in other living arrangements (11.4\%). No remarkable changes were found with regard to the respondents' reported social class and financial situations. The proportion of married respondents doubled from baseline to second follow-up (7.8\%).

\section{Separate Parent Investigation}

Given the resources available for the EDSP, we had to limit the parent investigation to direct parent interviews with only one parent of a subsample of respondents. Therefore, only parents of respondents aged 14-17 years at baseline who participated in the first follow-up investigation were included. Because we intended to gather detailed information not only about the occurrence of psychopathology in the respondents' families, but also about birth complications, psychological and somatic symptoms in the respondents' infancy and early childhood, we focused primarily on the respondents' mothers. Fathers were interviewed only if the mother was dead or not locatable. In 1997, the parents of 1,053 adolescents were interviewed directly, resulting in a response rate of $86 \%$. For 1,026 adolescents the mother was interviewed, and for 27 adolescents the father was interviewed. The respondent sample of 14- to 17-year-olds included four pairs of siblings; in these cases only one parent interview was conducted for each sibling pair, although separate information was gathered for each of the respondents. Nonresponse in parents was predominantly due to refusal to participate $(12.9 \%)$, failure to contact parents $(0.7 \%)$ and lack of time $(0.5 \%)$.

Figure 2 provides an overview of the number of respondents and response rates for the three waves of assessment (T0, T1, T2) as well as for the parent investigation.

\section{Instruments}

\section{Assessment of Adolescents and Young Adults}

In all three waves of investigation, symptoms and diagnostic assessments were based on the computer-assisted version of the Munich-Composite International Diagnostic Interview (M-CIDI) [30]. The M-CIDI is an updated version of the World Health Organization's CIDI version 1.2 [31] incorporating questions assessing DSM-IV [32] and ICD-10 [33] criteria. The M-CIDI allows for the standardized assessment of symptoms, syndromes and diagnoses of a wide range of DSM-IV substance use and mental disorders (and additional various subtypes of main disorders) along with information about onset, duration, clinical and psychosocial severity. (The complete M-CIDI is available on request.) Detailed descriptions of the MCIDI along with its assessment of substance use, abuse and dependence have already been described in detail elsewhere $[16,17]$. In the baseline investigation, the lifetime version of the M-CIDI was used to assess lifetime and 12-month information. For the two follow-up investigations, the M-CIDI was modified to cover the 12-month period prior to the follow-up interview as well as the remaining interval between the investigations (12-months interval version). To assess the course of disorders reported in prior investigations, a special lifetime chart was used in the second follow-up in which the respondent was asked to evaluate the duration and severity of every psychopathological problem reaching at least a subthreshold diagnostic level at baseline or either follow-up, covering the whole lifespan. Diagnostic assignment is based on the M-CIDI diagnostic package 'DSM-IV diagnostic algorithms' [30]. Due to the standardization and computerization of the interview and assignment of diagnoses the assessment can be regarded as highly objective.

In each wave, the respondents were given a special MCIDI response booklet with several symptom lists and visual aids to improve lifetime recall, facilitate memory search and help the respondent to answer onset and recen- 
Table 2. Distribution of sociodemographic variables in the baseline and second follow-up sample (aged 14-24 at baseline)

\begin{tabular}{|c|c|c|c|c|c|c|c|c|c|}
\hline & \multicolumn{9}{|c|}{ Baseline sample } \\
\hline & \multicolumn{3}{|c|}{$\begin{array}{l}\text { total } \\
(\mathrm{n}=3,021, \mathrm{nw}=3,021)\end{array}$} & \multicolumn{3}{|c|}{$\begin{array}{l}\text { men } \\
(\mathrm{n}=1,533, \mathrm{nw}=1,493)\end{array}$} & \multicolumn{3}{|c|}{$\begin{array}{l}\text { women } \\
(\mathrm{n}=1,488, \mathrm{nw}=1,528)\end{array}$} \\
\hline & $\mathrm{n}$ & $\% \mathrm{w}$ & $95 \% \mathrm{CI}$ & $\mathrm{n}$ & $\% \mathrm{w}$ & $95 \% \mathrm{CI}$ & $\mathrm{n}$ & $\% \mathrm{w}$ & $95 \% \mathrm{CI}$ \\
\hline \multicolumn{10}{|l|}{ Employment } \\
\hline School & 1,565 & 36.2 & $34.4-37.9$ & 804 & 36.8 & $34.4-39.4$ & 761 & 35.5 & $33.0-38.0$ \\
\hline University & 555 & 26.4 & $24.5-28.4$ & 282 & 27.3 & $24.7-30.1$ & 273 & 25.6 & $23.0-28.3$ \\
\hline Job training & 306 & 10.5 & $9.4-11.7$ & 165 & 11.2 & $9.6-13.0$ & 141 & 9.9 & $8.4-11.6$ \\
\hline Employed & 415 & 19.7 & $18.0-21.5$ & 171 & 16.4 & $14.2-18.8$ & 244 & 22.9 & $20.4-25.7$ \\
\hline Unemployed & 28 & 1.1 & $0.8-1.7$ & 18 & 1.4 & $0.9-2.3$ & 10 & 0.9 & $0.5-1.6$ \\
\hline Other & 152 & 6.1 & $5.2-7.2$ & 93 & 6.9 & $5.6-8.5$ & 59 & 5.3 & $4.1-6.9$ \\
\hline \multicolumn{10}{|l|}{ School type } \\
\hline Hauptschule & 166 & 3.1 & $2.6-3.6$ & 106 & 4.0 & $3.3-4.9$ & 60 & 2.2 & $1.7-2.9$ \\
\hline Realschule & 305 & 6.2 & $5.5-7.0$ & 148 & 6.1 & $5.1-7.2$ & 157 & 6.4 & $5.4-7.5$ \\
\hline Gymnasium & 993 & 24.0 & $22.5-25.5$ & 497 & 23.6 & $21.5-25.7$ & 496 & 24.4 & $22.3-26.6$ \\
\hline Fachoberschule & 41 & 1.4 & $1.0-1.9$ & 23 & 1.6 & $1.0-2.4$ & 18 & 1.1 & $0.7-1.8$ \\
\hline Other & 60 & 1.5 & $1.1-2.0$ & 30 & 1.6 & $1.1-2.4$ & 30 & 1.4 & $0.9-2.0$ \\
\hline No school & 1,456 & 63.9 & $62.1-65.6$ & 729 & 63.2 & $60.6-65.6$ & 727 & 64.5 & $62.0-67.0$ \\
\hline \multicolumn{10}{|l|}{ Living arrangements } \\
\hline With parents & 2,245 & 62.4 & $60.3-64.5$ & 1,208 & 67.3 & $64.4-70.2$ & 1,037 & 57.6 & $54.7-60.5$ \\
\hline Alone & 470 & 22.7 & $20.9-24.6$ & 219 & 22.2 & $19.6-24.9$ & 251 & 23.2 & $20.7-25.9$ \\
\hline With partner & 229 & 11.6 & $10.2-13.1$ & 78 & 8.2 & $6.6-10.2$ & 151 & 14.9 & $12.7-17.3$ \\
\hline Other & 77 & 3.4 & $2.6-4.3$ & 28 & 2.3 & $1.6-3.4$ & 49 & 4.4 & $3.2-5.9$ \\
\hline \multicolumn{10}{|l|}{ Social class } \\
\hline Lowest & 24 & 1.0 & $0.6-1.5$ & 17 & 1.4 & $0.8-2.3$ & 7 & 0.6 & $0.3-1.3$ \\
\hline Lower middle & 183 & 6.6 & $5.7-7.7$ & 104 & 7.3 & $5.9-8.9$ & 79 & 6.0 & $4.7-7.6$ \\
\hline Middle & 1,804 & 59.1 & $57.1-61.0$ & 877 & 57.3 & $54.5-60.1$ & 927 & 60.8 & $57.9-63.5$ \\
\hline Upper middle & 854 & 28.3 & $26.5-30.1$ & 451 & 28.7 & $26.2-31.3$ & 403 & 27.9 & $25.4-30.5$ \\
\hline Upper & 96 & 3.2 & $2.5-4.0$ & 52 & 3.3 & $2.4-4.5$ & 44 & 3.0 & $2.2-4.2$ \\
\hline None & 60 & 1.9 & $1.4-2.5$ & 32 & 2.0 & $1.4-3.0$ & 28 & 1.7 & $1.1-2.6$ \\
\hline \multicolumn{10}{|l|}{ Financial situation } \\
\hline Very bad, bad & 213 & 8.2 & $7.2-9.5$ & 117 & 9.4 & $7.8-11.3$ & 96 & 7.1 & $5.7-8.7$ \\
\hline Neither good nor bad & 830 & 28.0 & $26.3-29.9$ & 428 & 27.9 & $25.5-30.5$ & 402 & 28.2 & $25.7-30.8$ \\
\hline Good & 1,633 & 52.8 & $50.7-54.8$ & 814 & 52.0 & $49.1-54.8$ & 819 & 53.5 & $50.7-56.4$ \\
\hline Very good & 345 & 11.0 & $9.8-12.3$ & 174 & 10.7 & $9.1-12.5$ & 171 & 11.3 & $9.6-13.2$ \\
\hline \multicolumn{10}{|l|}{ Marital status } \\
\hline Married & 66 & 3.4 & $2.7-4.4$ & 17 & 1.8 & $1.1-3.0$ & 49 & 4.9 & $3.7-6.6$ \\
\hline Separated & 5 & 0.3 & $0.1-0.7$ & 1 & 0.1 & $0.0-1.0$ & 4 & 0.4 & $0.2-1.1$ \\
\hline Divorced & 1 & 0.1 & $0.0-0.4$ & 0 & 0.0 & & 1 & 0.1 & $0.0-0.8$ \\
\hline \multicolumn{10}{|l|}{ Widowed } \\
\hline Never married & 2,949 & 96.3 & $95.3-97.1$ & 1,515 & 98.0 & $96.8-98.8$ & 1,434 & 94.6 & $92.9-95.9$ \\
\hline
\end{tabular}

cy questions of reported symptoms. Furthermore, the response booklet contained several scales and questionnaires to assess selected psychological constructs. In addition to the information concerning the respondents' own behaviors and history, the baseline and second follow-up interviews included a separate family history module of the M-CIDI to evaluate substance use, substance use disorder and history of psychopathology in parents and other family members of the respondents (siblings and grandparents). 


\begin{tabular}{|c|c|c|c|c|c|c|c|c|}
\hline \multicolumn{9}{|c|}{ Second follow-up } \\
\hline \multicolumn{3}{|c|}{$\begin{array}{l}\text { total } \\
(\mathrm{n}=2,548, \mathrm{nw}=2,547)\end{array}$} & \multicolumn{3}{|c|}{$\begin{array}{l}\text { men } \\
(\mathrm{n}=1,297, \mathrm{nw}=1,262)\end{array}$} & \multicolumn{3}{|c|}{$\begin{array}{l}\text { women } \\
(\mathrm{n}=1,262, \mathrm{nw}=1,284)\end{array}$} \\
\hline $\mathrm{n}$ & $\% \mathrm{w}$ & $95 \% \mathrm{CI}$ & $\mathrm{n}$ & $\% \mathrm{w}$ & $95 \% \mathrm{CI}$ & $\mathrm{n}$ & $\% \mathrm{w}$ & $95 \% \mathrm{CI}$ \\
\hline 560 & 12.8 & $11.7-14.0$ & 291 & 13.0 & $11.5-14.7$ & 269 & 12.6 & $11.1-14.3$ \\
\hline 559 & 25.6 & $23.7-27.5$ & 291 & 26.1 & $23.5-29.0$ & 268 & 25.0 & $22.3-27.8$ \\
\hline 386 & 10.9 & $9.8-12.2$ & 205 & 11.5 & $9.9-13.3$ & 181 & 10.4 & $8.9-12.1$ \\
\hline 714 & 36.2 & $34.1-38.5$ & 344 & 35.2 & $32.2-38.3$ & 370 & 37.3 & $34.2-40.4$ \\
\hline 26 & 1.1 & $0.7-1.7$ & 9 & 0.7 & $0.3-1.4$ & 17 & 1.6 & $0.9-2.7$ \\
\hline 303 & 13.3 & $11.9-14.9$ & 157 & 13.5 & $11.5-15.8$ & 146 & 13.2 & $11.2-15.5$ \\
\hline 2 & 0.0 & $0.0-0.2$ & 1 & 0.0 & $0.0-0.3$ & 1 & 0.1 & $0.0-0.3$ \\
\hline 32 & 0.6 & $0.4-0.9$ & 21 & 0.8 & $0.5-1.2$ & 11 & 0.4 & $0.2-0.8$ \\
\hline 426 & 9.5 & $8.6-10.5$ & 218 & 9.4 & $8.2-10.8$ & 208 & 9.6 & $8.3-11.1$ \\
\hline 75 & 1.9 & $1.5-2.4$ & 39 & 2.1 & $1.5-2.9$ & 36 & 1.7 & $1.2-2.4$ \\
\hline 25 & 0.8 & $0.5-1.2$ & 12 & 0.8 & $0.4-1.4$ & 13 & 0.8 & $0.5-1.5$ \\
\hline 1,988 & 87.2 & $86.0-88.3$ & 1,006 & 87.0 & $85.3-88.5$ & 982 & 87.4 & $85.7-88.9$ \\
\hline 1,368 & 40.2 & $38.2-42.3$ & 767 & 45.3 & $42.4-48.3$ & 601 & 35.2 & $32.5-38.0$ \\
\hline 509 & 25.7 & $23.7-27.7$ & 274 & 28.2 & $25.4-31.2$ & 235 & 23.2 & $20.5-26.1$ \\
\hline 421 & 22.7 & $20.8-24.8$ & 147 & 16.6 & $14.2-19.4$ & 274 & 28.7 & $25.8-31.8$ \\
\hline 250 & 11.4 & $10.1-12.9$ & 109 & 9.8 & $8.1-11.9$ & 141 & 12.9 & $10.9-15.3$ \\
\hline 14 & 0.5 & $0.3-0.9$ & 8 & 0.6 & $0.3-1.2$ & 6 & 0.5 & $0.2-1.1$ \\
\hline 230 & 9.8 & $8.6-11.2$ & 127 & 10.5 & $8.8-12.5$ & 103 & 9.1 & $7.4-11.1$ \\
\hline 1,524 & 60.2 & $58.1-62.3$ & 741 & 58.6 & $55.6-61.6$ & 783 & 61.8 & $58.8-64.8$ \\
\hline 682 & 25.6 & $23.7-27.5$ & 371 & 26.4 & $23.8-29.1$ & 311 & 24.8 & $22.2-27.6$ \\
\hline 53 & 2.0 & $1.5-2.6$ & 34 & 2.5 & $1.7-3.6$ & 19 & 1.5 & $0.9-2.4$ \\
\hline 45 & 2.0 & $1.4-2.7$ & 16 & 1.5 & $0.9-2.5$ & 29 & 2.4 & $1.6-3.6$ \\
\hline 151 & 6.8 & $5.8-8.0$ & 73 & 6.5 & $5.1-8.2$ & 78 & 7.2 & $5.7-9.0$ \\
\hline 738 & 28.9 & $27.0-31.0$ & 393 & 30.2 & $27.4-33.0$ & 345 & 27.7 & $25.0-30.6$ \\
\hline 1,367 & 53.7 & $51.6-55.9$ & 666 & 51.1 & $48.0-54.2$ & 701 & 56.4 & $53.2-59.4$ \\
\hline 269 & 10.5 & $9.2-12.0$ & 161 & 12.3 & $10.4-14.5$ & 108 & 8.8 & $7.1-10.8$ \\
\hline 133 & 7.8 & $6.5-9.2$ & 42 & 5.2 & $3.8-7.1$ & 91 & 10.3 & $8.4-12.7$ \\
\hline 3 & 0.2 & $0.1-0.7$ & 0 & 0.0 & & 3 & 0.4 & $0.1-1.4$ \\
\hline 12 & 0.8 & $0.4-1.4$ & 4 & 0.5 & $0.2-1.3$ & 8 & 1.0 & $0.5-2.1$ \\
\hline 1 & 0.0 & $0.0-0.1$ & 0 & 0.0 & & 1 & 0.0 & $0.0-0.3$ \\
\hline 2,399 & 91.2 & $89.7-92.6$ & 1,251 & 94.3 & $92.4-95.8$ & 1,148 & 88.2 & $85.7-90.3$ \\
\hline
\end{tabular}

\section{Reliability and Validity of the M-CIDI}

Reliability and procedural validity of the M-CIDI were tested in several studies. Briefly, test-retest reliability (retest after an average period of 39 days, $n=60$ of the community sample) was fair to good for substance use disor- ders, ranging from $\kappa=0.64$ (Yules $Y=0.80$ ) for drug use disorders to $\kappa=0.78$ (Yules $Y=0.82$ ) for alcohol use disorders [34]. Procedural clinical validity was examined in 68 patients comparing M-CIDI diagnoses with clinicians' best-estimate diagnoses and taking into account all avail- 


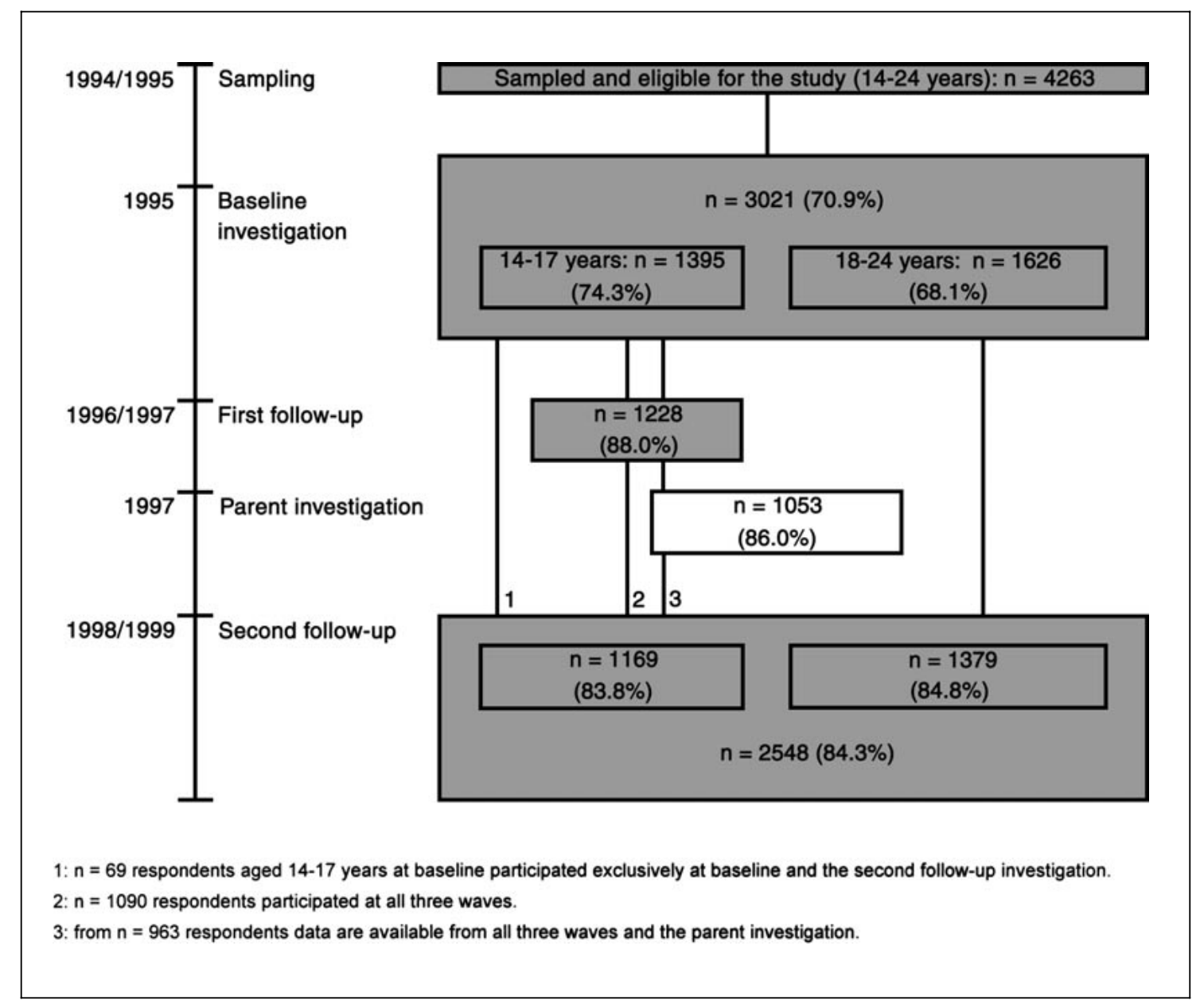

Fig. 2. Overview over number of respondents and response rates of the different EDSP waves.

able information (medical records, diagnostic interview, diagnostic checklist) at the end of the patients' treatment [35]. For substance use disorders the agreement was very good, with $\kappa=0.86$ for any substance use disorder and $\kappa=$ 0.83 for nicotine dependence. Measures of sensitivity and specificity were excellent for substance use disorders. Detailed analyses covering validity and reliability of single diagnostic criteria and age, frequency and quantity information are provided elsewhere [17, 34-36].

\section{Assessment of Other Psychological Constructs}

As noted above, the M-CIDI was supplemented by a separate response booklet that included several scales and questionnaires for assessing relevant psychological constructs. Descriptions of some of these constructs as well as the assessment instruments have already been published partially in previous papers $[10,16,27]$. Table 3 provides an overview over the constructs and instruments used together with their time of assessment.

\section{The EDSP Family Supplement (EDSP-FS)}

The main goals of the EDSP-FS are (1) to explore how familial psychopathology is linked to the onset, course and comorbidity of mental disorders in children, (2) to elucidate the interplay of familial psychopathology and familial socialization factors, and (3) to investigate familial aggregation of mental disorders on the basis of a representative community sample. Using detailed diagnostic information about the presence of psychopathology in the grandparents, parents and siblings of all respondents, the specificity and comorbidity of the familial aggregation of mental disorders is being studied as well as the impact of 
Table 3. Measures used in the EDSP study to assess major constructs

\begin{tabular}{|c|c|c|c|c|}
\hline \multirow[t]{2}{*}{ Construct } & \multirow[t]{2}{*}{ Assessment instrument } & \multicolumn{3}{|c|}{ Time of assessment } \\
\hline & & $\mathrm{T} 0$ & $\mathrm{~T} 1$ & $\mathrm{~T} 2$ \\
\hline \multicolumn{5}{|l|}{ Substance-related variables } \\
\hline Use of psychotropic substances (age of onset, quantity, frequency) & Specific substance sections of the M-CIDI & $\mathrm{x}$ & $\mathrm{x}$ & $\mathrm{x}$ \\
\hline DSM-IV substance abuse and dependence & Specific substance sections of the M-CIDI & $\mathrm{x}$ & $\mathrm{x}$ & $\mathrm{x}$ \\
\hline Substance use situations, use in peer group, availability & Specific questions within the substance sections of the M-CIDI & $\mathrm{x}$ & & \\
\hline Motivation for smoking & Fragebogen zur Erfassung des Gesundheitsverhaltens [37] ${ }^{1}$ & $\mathrm{x}$ & $\mathrm{x}$ & $\mathrm{x}$ \\
\hline Motivation for drinking alcohol & Fragebogen zur Erfassung des Gesundheitsverhaltens [37 ${ }^{1}$ & $\mathrm{x}$ & $\mathrm{x}$ & $\mathrm{x}$ \\
\hline Alcohol outcome expectancies & Effects of Drinking Alcohol Scale [38] & $\mathrm{x}$ & $\mathrm{x}$ & $\mathrm{x}$ \\
\hline Motivation for taking drugs & Fragebogen zur Erfassung des Gesundheitsverhaltens [37 $]^{1}$ & & $\mathrm{x}$ & $\mathrm{x}$ \\
\hline \multicolumn{5}{|l|}{ Other intrapersonal variables } \\
\hline Anxiety disorder & Anxiety disorder section of the M-CIDI & $\mathrm{x}$ & $\mathrm{x}$ & $\mathrm{x}$ \\
\hline Affective disorder & Affective disorder section of the M-CIDI & $\mathrm{x}$ & $\mathrm{x}$ & $\mathrm{x}$ \\
\hline \multirow[t]{2}{*}{ Any other mental disorder } & Somatoform disorder, eating disorder and posttraumatic stress & & & \\
\hline & $\begin{array}{l}\text { disorder section of the M-CIDI } \\
\text { Specific M-CIDI module }\end{array}$ & $\begin{array}{l}\mathrm{x} \\
\mathrm{x}\end{array}$ & $\begin{array}{l}\mathrm{x} \\
\mathrm{x}\end{array}$ & $\begin{array}{l}\mathrm{x} \\
\mathrm{x}\end{array}$ \\
\hline Health behavior & Fragebogen zur Erfassung des Gesundheitsverhaltens [37 $]^{1}$ & $\begin{array}{l}x \\
\mathrm{x}\end{array}$ & & \\
\hline Psychiatric symptom distress & Symptom Checklist 90 Revised [39] & $\mathrm{x}$ & $\mathrm{x}$ & $\mathrm{x}$ \\
\hline Live events & Münchner Ereignis-Liste [40] & $\mathrm{x}$ & $\mathrm{x}$ & $\mathrm{x}$ \\
\hline Self-esteem & Vergleich von Kompetenzen Skala [41] & $\mathrm{x}$ & & \\
\hline Self-esteem/competence & Aussagen-Liste zum Selbstwertgefühl für Kinder und Jugendliche [42] & $\mathrm{x}$ & & \\
\hline Self-control and coping skills & Skala zur Erfassung von Problemlösekompetenzen [43] & $\mathrm{x}$ & & \\
\hline Behavioral inhibition & Retrospective self-report of inhibited behavior during childhood [44] & $\mathrm{x}$ & & \\
\hline Daily stressors/hassles & Daily Hassles Scale [45] & $\mathrm{x}$ & $\mathrm{x}$ & $\mathrm{x}$ \\
\hline Recalled parental rearing behavior & Fragebogen zum erinnerten Erziehungsverhalten [46] & & $\mathrm{x}$ & $\mathrm{x}$ \\
\hline Mood & Stimmungsskala [47] & & $\mathrm{x}$ & \\
\hline Affect lability & Affect lability scale [48] & & $\mathrm{x}$ & $\mathrm{x}$ \\
\hline Resilience & Resilience scale [49] & & $\mathrm{x}$ & \\
\hline Volition & Selbststeuerungsinventar [50] & & & $\mathrm{x}$ \\
\hline \multicolumn{5}{|l|}{ Disorder-specific variables } \\
\hline Premenstrual symptoms & Premenstrual Symptom Scale [51] & $\mathrm{x}$ & $\mathrm{x}$ & $\mathrm{x}$ \\
\hline Depression (attribution) & Reason for Depression Questionnaire [52] & & $\mathrm{x}$ & \\
\hline Suicide attempt & Fragebogen zu Selbstmordversuchen [53] & & & $\mathrm{x}$ \\
\hline Panic (health belief model) & Erleben des ersten Angstanfalls [54] & & $\mathrm{x}$ & $\mathrm{x}$ \\
\hline Antisocial behavior & Antisocial personality disorder scale and questions of the SCID-II [55 $]^{1}$ & & & $\mathrm{x}$ \\
\hline
\end{tabular}

1 Modified version.

different manifestations of familial loading of psychopathology on the onset and course of mental disorders.

In general, there are two basic methodological approaches to assess psychopathology in family members: (1) the family study method, which involves the direct interview of each family member concerning his or her own symptoms, and (2) the family history method, which involves obtaining diagnostic information from the respondent or a relative as an informant about all other family members. Advantages and limitations of each approach have been discussed [56-59]. Taking into account what could realistically be assessed in a large community sample - (a) the collection of family history information about all first-degree relatives of the respondents, using the respondent as informant, and (b) the additional

Early Developmental Stages of

Psychopathology Study assessment of direct diagnostic information about parental psychopathology from respondents' parents as a second source was chosen as strategy to gather the best information possible about familial psychopathology.

(a) In the EDSP, family history information about psychopathology in the respondents' relatives was assessed by specific M-CIDI family history modules that were administered at baseline (T0) and second follow-up (T2) to all EDSP respondents. Family history items were designed taking the Family History Research Diagnostic Criteria [60] as a basic model. In the baseline investigation, the stem questions from the full M-CIDI were used to obtain fmily history information for the mothers and fathers of respondents, about the same DSM-IV axis I disorders that are in the M-CIDI. Additional questions were 
asked to determine if any of the respondents' first-degree relatives had ever sought professional help because of a mental disorder or substance abuse problem. For the second follow-up survey, an extended version of the M-CIDI family history module was developed that contained fully structured sections covering DSM-IV criteria for nicotine dependence, major depression, manic episodes, anxiety disorders (panic disorder, agoraphobia, social phobia, specific phobia, generalized anxiety disorder), alcohol and drug abuse and dependence, and bulimic attacks. Respondents provided information about their parents and siblings. For siblings younger than 10 years old, only separation anxiety was assessed.

(b) Although the most accurate strategy for the additional assessment of familial psychopathology in respondents' parents would have been to conduct direct interviews with all mothers and all fathers, resources limited us to directly interviewing only the parents of the subsample of the 14- to 17-year-olds, as well as to only one parent (predominantly the mother) of each respondent. The parents of 1,053 adolescents (see above) were independently assessed with the M-CIDI, thus providing full diagnostic information (M-CIDI/DSM-IV criteria) for the interviewed parents [61]. Similar to the family history module used in the baseline investigation, the parent M-CIDI included a family history module that collected family history data about the same DSM-IV axis I disorders that are in the M-CIDI disorders in the noninterviewed parents as well as in the respondents' grandparents. Information about alcohol use disorders was also assessed for parents' brothers and sisters [62].

\section{Assessment of Information about Familial}

\section{Socialization and Childhood Variables}

Information about familial socialization variables, such as parenting style or family functioning characteristics, that might be important in the development of substance use and other mental disorders were assessed from the respondents themselves as well as from the interviewed parents. Furthermore, information about respondents' childhood developmental characteristics (e.g. birth complications, childhood disorders) was collected from the interviewed parents. Table 4 provides an overview of the main familial psychopathology, family environment, socialization and early developmental constructs assessed in the different EDSP assessment stages.

\section{Field Work}

\section{Interviewer and Interviewer Training}

In all assessment stages interviews were conducted by a total of 57 clinical interviewers, mostly graduated psychologists; 25 professional health research interviewers recruited from a survey company (Infratest Gesundheitsforschung) were additionally involved in the baseline investigation. Parent interviews were predominantly conducted by female interviewers in the age range of the targeted mothers. Interviewers of the parent study were blind to the diagnoses of the respondents.

All interviewers participated in 1 week of training for both the computerized and the paper-pencil version of the M-CIDI. This was followed by at least 10 practice interviews that were closely monitored and supervised by the staff of the study. Immediately prior to the beginning of the field work for the baseline investigation, there was a 1-day booster session to stress important points and techniques and increase the motivation of the interviewers. Before each of the follow-ups and the parent study, an intensive M-CIDI training session took place, which emphasized special features and changes in the version of the interview used in that stage of the study. Many interviewers conducted interviews in several waves of the EDSP so that they can be called to be very experienced in carrying out M-CIDI interviews (for further details of recruitment of interviewers, see Wittchen et al. [16]). During field work all interviewers were regularly supervised by specially trained M-CIDI clinical editors from the Max Planck Institute. All interviews were checked according to a standard procedure for both formal consistency as well as appropriate recording and coding. During weekly editing sessions, detailed feedback was given to every interviewer to avoid errors in later interviews and to clarify remaining questions. The editors also gave instructions for reassessment of missing values or questionnaires.

For the success of the study, primarily in terms of response rates, it was necessary to promote and maintain high motivation of the respondents throughout the entire study period. Before the baseline investigation, all sampled subjects received a letter with information about the aims, objectives and methodology (interview) of the study. The letter explained how data would be protected and that participation was voluntary. Respondents were told that they would be contacted by telephone to schedule an interview. The respondents were free to choose the time and place for the interview, and most interviews took place in the respondent's home. Two telephone cards worth DM 12 (USD 6) were given to respondents as an 
Table 4. Family and early childhood variables assessed in the different waves and parent investigation of the EDSP

\begin{tabular}{|c|c|c|c|c|}
\hline \multirow[t]{2}{*}{ Construct } & \multicolumn{4}{|c|}{ Assessment stage ${ }^{1}$} \\
\hline & T0 & $\mathrm{T} 1$ & $\mathrm{~T} 2$ & $\mathrm{P}$ \\
\hline \multicolumn{5}{|l|}{ Familial psychopathology } \\
\hline History of mental disorders in parents & $\mathrm{x}$ & - & $\mathrm{x}$ & $\mathrm{x}$ \\
\hline History of mental disorders in siblings & - & - & $\mathrm{x}$ & - \\
\hline History of mental disorders in grandparents & - & - & - & $\mathrm{x}$ \\
\hline \multicolumn{5}{|l|}{ Familial stress $^{2}$} \\
\hline Death of parents & $\mathrm{x}$ & - & - & $\mathrm{x}$ \\
\hline Divorce of parents & $\mathrm{x}$ & - & - & $\mathrm{x}$ \\
\hline Familial stress events during the last 5 years & $\mathrm{x}$ & - & - & - \\
\hline Sociodemographics of parents & - & - & - & $\mathrm{x}$ \\
\hline Early parenthood of respondents' parents & - & - & - & $\mathrm{x}$ \\
\hline Financial situation of the family (in respondents', first 5 years of life) & - & - & - & $\mathrm{x}$ \\
\hline Social situation of mother (in respondents', first 5 years of life) & - & - & - & $\mathrm{x}$ \\
\hline Mental health of mother (in respondents', first 5 years of life) & - & - & - & $\mathrm{x}$ \\
\hline Physical health of mother (in respondents', first 5 years of life) & - & - & - & $\mathrm{x}$ \\
\hline \multicolumn{5}{|l|}{ Familial relationship ${ }^{3}$} \\
\hline Actual relationship to mother and father & $\mathrm{x}$ & - & - & - \\
\hline Family functioning & - & - & - & $\mathrm{x}$ \\
\hline Parental educational style & - & - & - & $\mathrm{x}$ \\
\hline Familial relationships & - & - & - & $\mathrm{x}$ \\
\hline Recalled parenting rearing behavior & - & $\mathrm{x}$ & $\mathrm{x}$ & - \\
\hline \multicolumn{5}{|l|}{ Familial substance environment ${ }^{4}$} \\
\hline Parental attitude towards legal, illegal drugs & $\mathrm{x}$ & - & - & - \\
\hline Availability of alcohol, medications at home & $\mathrm{x}$ & - & - & - \\
\hline \multicolumn{5}{|l|}{ Childhood development characteristics ${ }^{5}$} \\
\hline Natal complications & - & - & - & $\mathrm{x}$ \\
\hline Somatic symptoms, sensory symptoms, physical disabilities & - & - & - & $\mathrm{x}$ \\
\hline ADHD & - & - & - & $\mathrm{x}$ \\
\hline Conduct disorder & - & - & - & $\mathrm{x}$ \\
\hline Oppositional defiant disorder & - & - & - & $\mathrm{x}$ \\
\hline Marked affect lability & - & - & - & $\mathrm{x}$ \\
\hline Help-seeking behavior in infancy and childhood & - & - & - & $\mathrm{x}$ \\
\hline
\end{tabular}

$1 \mathrm{~T} 0=$ Baseline investigation, informants are baseline respondents (total $n=3,021)$; $\mathrm{T} 1=$ first follow-up investigation, informants are respondents of first follow-up (total $\mathrm{n}=1,228$ ); $\mathrm{T} 2=$ second follow-up investigation, informants are respondents of second follow-up (total $\mathrm{n}=2,548$ ); $\mathrm{P}=$ parent investigation, Informants are interviewed parents of respondents (total $\mathrm{n}=1053$ ).

2 Standard questions about family stress assessed in the sociodemographic M-CIDI module (T0) and the family environment/childhood development M-CIDI module of the parent survey.

3 Assessment of familial relationship: actual relationship to mother and father: standard question in the sociodemographic M-CIDI module (T0); family functioning: Family Assessment Device [63]; parental educational style: Skala elterlicher Erziehungsmassnahmen [64]; familial relationships: Subjektives Familienbild [65]; Recalled parenting rearing behavior: Fragebogen zum erinnerten elterlichen Erziehungsverhalten [46].

4 The familial substance environment was assessed in the family history module of the M-CIDI.

5 The childhood development characteristics were assessed from directly interviewed parents $($ total $n=1,053)$ in the family environment/childhood development M-CIDI-module of the M-CIDI used in the parent survey; natal complications, somatic and sensory symptoms and physical disabilities were assessed by a standardized checklist [10]; attention-deficit/hyperactivity disorder (ADHD), conduct disorder and oppositional defiant disorder were assessed with questions covering the criteria defined by the DSM-IV. 
incentive for participation. Informed consent of the parents was obtained for respondents under the age of 18 years. To increase participation, several special efforts were made: (a) addresses of subjects who were contacted several times without success were given to another interviewer of the opposite sex, (b) at least 10 attempts to contact each subject were made at different times of the day and week, including evenings and weekends, (c) interviewers who were especially successful in contacting were trained to recontact subjects who were difficult to reach, (d) motivation letters were sent to unreachable subjects with a telephone card enclosed to call back, and (e) up to DM 50 (USD 25) was offered to motivate the most indecisive subjects to participate.

The field work of the follow-ups entailed a lot of effort to relocate all of the respondents. Due to the high mobility of the examined age group (e.g. moving out of the parents' home, moving to another town to go to university) and changes of last names after marriage, diligent searches were necessary to locate these subjects. All but $1.7 \%$ of subjects could finally be located and recontacted. Subjects who had moved to foreign countries during the follow-up period were contacted by telephone and asked to participate in a telephone interview. Telephone interviews consisted of the M-CIDI conducted in the same way as the face-to-face interview. Subjects who had moved to another city in Germany were visited at their new residence for a face-to-face interview. If it was not possible to conduct a face-to-face interview, telephone interviews analogous to those with subjects living in foreign countries were conducted.

\section{Statistical Aspects}

\section{Measures}

As described above (fig. 1), the EDSP study design entailed a baseline assessment (T0) and two follow-up interviews (T1, T2) that were held at approximately 18month intervals. Following this longitudinal panel design, retrospective data (lifetime symptomatology assessed at baseline) is combined with prospective data (follow-up incidence). Interim symptomatology between the baseline and the two follow-up investigations was assessed at each follow-up by using the 12-month interval version of the M-CIDI. With information from the three assessments the following measures can be derived: lifetime and crosssectional prevalence rates and incidence rates. For crosssectional prevalence and incidence, several time frames can be considered (e.g. 12-month or interim). For defini- tions and more detailed descriptions of these and other commonly used epidemiological terms and measures see Wittchen et al. [16].

\section{Sample and Weighting}

As the EDSP is designed with special interest in early stages of psychopathology, 14- to 15-year-olds were sampled at twice the probability of 16- to 21 -year-olds, and 22- to 24-year-olds were sampled at half this probability $[8,16]$. This sampling strategy allows particularly precise estimations of measures used for comparative analyses for the age group of primary interest, i.e. 14- to 15-yearolds. Due to the different sampling probabilities, relative weights inversely proportional to the sampling fraction are used in the estimation of measures which are generalized to the sampling frame. In addition, these weights also account for nonresponse according to age, gender and geographic distribution (urban vs. rural) of the respondents to that of the registered sampling frame. For data from the first follow-up investigation which included only the 14to 17 -year-olds, a special weight was computed for the subpopulation of the younger cohort, also adjusting for dropout from baseline to first follow-up according to age, gender, geographic distribution and nonresponse. For data from the second follow-up, the same weights as those of the baseline investigation are used, because there was no selective attrition due to age, gender or geographic distribution for which we had to adjust.

\section{Comment}

Unique features of the EDSP are (1) a combined longitudinal characterization of psychopathology and substance use behaviors and disorders, and (2) a prospectivelongitudinal assessment of various risk and protective factors that are involved in the development of substance use and other mental disorders (3) in a representative sample of adolescents and (4) young adults along with a characterization of family factors. Prospective-longitudinal designs in representative population samples, as used in our study, are essential for an unbiased characterization of the psychopathological status of the population and the identification of putative risk factor constellations, since clinical samples are usually influenced by selection bias and in general allow only for retrospective approaches. Therefore, the different design features of the EDSP and its family supplement provide the unique opportunity of not only describing prevalence and prospectively observed incidence patterns of substance use and mental disorders 
in the target population on various diagnostic levels (asymptomatic, symptomatic, subthreshold and full diagnostic level), but they also offer an adequate basis for investigating a variety of familial, cognitive-behavioral and social risk factors and in particular their status as causal risk factors. Further, the EDSP allows to study various public-health-related consequences of substance use and other mental disorders prospectively and unaffected by recall bias. Besides these strengths of the design features of the EDSP, the quality of the assessed data has to be outlined: the collected data are based on comprehensive standardized interviews, which were conducted by trained and highly experienced interviewers. Furthermore, the response rates in the different waves of investigation (ranging from 70.9 to $88.0 \%$ ) as well as the overall response rate of $84.3 \%$ must be seen as most successful. Taking these strengths into account, the aims and objectives of the EDSP can be pursued in the frame of a unique design and excellent data.

\section{Acknowledgements}

This work is part of EDSP Study and is funded by the German Ministry of Research and Technology, project No. 01 EB 9405/6 and 01 EB 9901/6. The principal investigators are Dr. Hans-Ulrich Wittchen and Dr. Roselind Lieb. Current or former staff members of the EDSP group are Dr. Kirsten von Sydow, Dr. Gabriele Lachner, Dr. Axel Perkonigg, Dr. Peter Schuster, Dr. Franz Gander, Dipl.Stat. Michael Höfler and Dipl.-Psych. Holger Sonntag as well as Mag. phil. Esther Beloch, Mag. rer. nat. Martina Fuetsch, Dipl.-Psych. Elzbieta Garczynski, Dipl.-Psych. Alexandra Holly, Dipl.-Psych. Barbara Isensee, Dipl.-Psych. Marianne Mastaler, Dr. Chris Nelson, Dipl.Inf. Hildegard Pfister, Dr. Victoria Reed, Dipl.-Psych. Dilek Türk, Dipl.-Psych. Antonia Vossen, Dr. Ursula Wunderlich and Dipl.Psych. Petra Zimmermann. Scientific advisors are Dr. Jules Angst (Zurich), Dr. Jürgen Margraf (Basel), Dr. Günther Esser (Mannheim), Dr. Kathleen Merikangas (Yale, New Haven) and Dr. Ron Kessler (Harvard, Boston). The authors wish to acknowledge the many helpful comments and the considerable help in editing and revising the manuscript by Robin Carter.

\section{References}

1 Nelson CB, Wittchen H-U: The EDSP: Setting the stage! (editorial). Eur Addict Res 1998;4: $5-7$.

2 Research Group ANEPSA: Epidemiological research in Germany. Eur Addict Res 1998;4: 203-204.

3 John U: Analytische Epidemiologie des Substanzmissbrauchs in Deutschland (editorial). Sucht 2000;46:6-8.

4 Küfner H, Schumann J, Duwe A, Bühringer G: Project 1: Longitudinal risk cohort study on the onset, course, prevalence and prevention of illegal drug abuse. Eur Addict Res 1998;4:205206.

5 Lieb R, Schuster P, Pfister H, Wunderlich Z, Holly A, Mastaler M, Sonntag H, Gander F, Höfler M, Lachner G, Perkonigg A, Garczynski E, Türk D, Wittchen H-U: Projects 2 and 3: Vulnerability and protective factors in early developmental stages of substance use disorders. Eur Addict Res 1998:4:206-207.

6 Hapke U, Rumpf H-J, Meyer C, Dilling H, John U: Project 4: Substance use, abuse and dependence among the adult population in a rural and urban region of Northern Germany. Eur Addict Res 1998;4:208-209.

7 Rumpf H-J, Hapke U, Dawedeit A, Meyer C, John U: Project 5: Triggering and maintenance factors of remitting from alcohol dependence without formal help. Eur Addict Res 1998;4: 209-210.

8 Wittchen H-U, Nelson GB, Lachner G: Prevalence of mental disorders and psychosocial impairments in adolescents and young adults. Psychol Med 1998;28:109-126.
9 Wittchen H-U, Lieb R, Perkonigg A: Early developmental stages of substance abuse and dependence: Examples from a prospective longitudinal study; in Ladewig D (ed): Basic and Clinical Science of Substance-Related Disorders. Bibl Psychiatr. Basel, Karger, 1999, pp 722.

10 Wittchen H-U, Lieb R, Schuster P, Oldehinkel $\mathrm{T}$ : When is onset? Investigations into early developmental stages of anxiety and depressive disorders; in Rapoport JL (ed): Childhood Onset of 'Adult' Psychopathology, Clinical and Research Advances. Washington, American Psychiatric Press, 1999, pp 259-302.

11 Lieb R, Schuster P, Pfister H, Fuetsch M, Höfler M, Isensee B, Müller N, Sonntag H, Wittchen H-U: Epidemiologie des Konsums, Missbrauchs und der Abhängigkeit von legalen und illegalen Drogen bei Jugendlichen und jungen Erwachsenen: Die prospektiv-longitudinale Verlaufsstudie EDSP. Sucht 2000;46:18-31.

12 Rumpf H-J, Meyer Ch, Hapke U, Bischof G, John U: Inanspruchnahme suchtspezifischer Hilfen von Alkoholabhängigen und -missbrauchern: Ergebnisse der TACOS-Bevölkerungsstudie. Sucht 2000;46:9-17.

13 Küfner H, Duwe A, Schumann J, Bühringer G: Prädiktoren des Drogenkonsums und der Suchtentwicklung durch Faktoren in der Kindheit: Grundlagen und Ergebnisse einer empirischen Studie. Sucht 2000;46:32-53.

14 Bischof G, Rumpf H-J, Hapke U, Meyer C, John U: Remission ohne formelle Hilfen und Inanspruchnahme stationärer Behandlung bei Alkoholabhängigen: Ein Vergleich auslösender Faktoren. Sucht 2000;46:54-61.
15 Perkonigg A, Lieb R, Wittchen H-U: Substance use, abuse and dependence in Germany: A review of selected epidemiological data. Eur Addict Res 1998;4:8-17.

16 Wittchen H-U, Perkonigg A, Lachner G, Nelson $\mathrm{CB}$ : Early developmental stages of psychopathology study (EDSP): Objectives and design. Eur Addict Res 1998;4:18-27.

17 Lachner G, Wittchen H-U, Perkonigg A, Holly A, Schuster P, Wunderlich U, Türk D, Garczynski E, Pfister H: Structure, content and reliability of the Munich-Composite International Diagnostic Interview (M-CIDI): Substance use sections. Eur Addict Res 1998;4:28-41.

18 Nelson CB, Wittchen H-U: Smoking and nicotine dependence: Results from a sample of 14to 24-year-olds in Germany. Eur Addict Res 1998;4:42-49.

19 Holly A, Wittchen H-U: Patterns of use and their relationship to DSM-IV abuse and dependence of alcohol among adolescents and young adults. Eur Addict Res 1998;4:50-57.

20 Perkonigg A, Lieb R, Wittchen H-U: Prevalence of use, abuse and dependence of illicit drugs among adolescents and young adults in a community sample. Eur Addict Res 1998;4: 58-66.

21 Lieb R, Pfister H, Wittchen H-U: Use, abuse and dependence of prescription drugs in adolescents and young adults. Eur Addict Res 1998:4:67-74.

22 Schuster P, Lieb R, Lamertz C, Wittchen H-U: Is the use of ecstasy and hallucinogens increasing? Results from a community study. Eur Addict Res 1998;4:75-82. 
23 Schuster P, Wittchen HU: Ecstasy- und Halluzinogengebrauch bei Jugendlichen: Gibt es eine Zunahme? Verhaltenstherapie 1996;6:222232.

24 Holly A, Türk D, Nelson CB, Pfister H, Wittchen H-U: Prävalenz von Alkoholkonsum, Alkoholmissbrauch und -abhängigkeit bei Jugendlichen und jungen Erwachsenen. Z Klin Psychol 1997;26:171-178.

25 Perkonigg A, Beloch E, Garczynski E, Nelson $\mathrm{CB}$, Pfister H, Wittchen $\mathrm{H}-\mathrm{U}$ : Prävalenz von Drogenmissbrauch und -abhängigkeit bei Jugendlichen und jungen Erwachsenen: Gebrauch, Diagnosen und Auftreten erster Missbrauchs- und Abhängigkeitsmerkmale. Z Klin Psychol 1997;26:247-257.

26 Wittchen H-U, Höfler M, Perkonigg A, Sonntag H, Lieb R: Wie stabil sind Drogenkonsum und das Auftreten klinisch-diagnostisch relevanter Missbrauchs- und Abhängigkeitsstadien be Jugendlichen? Eine epidemiologische Studie am Beispiel von Cannabis. Kindheit Entwicklung 1998;7:188-198.

27 Höfler M, Lieb R, Perkonigg A, Schuster P, Sonntag H, Wittchen H-U: Covariates of cannabis use progression in a representative population sample of adolescents: A prospective examination of vulnerability and risk factors. Addiction 1999;94:1679-1694.

28 Perkonigg A, Lieb R, Höfler M, Schuster P, Sonntag H, Wittchen H-U: Patterns of cannabis use, abuse and dependence over time: Incidence, progression and stability in a sample of 1,228 adolescents. Addiction 1999;94:16631678.

29 Sonntag H, Wittchen H-U, Höfler M, Kessler RC, Stein MB: Are social fears and DSM-IV social anxiety disorder associated with smoking and nicotine dependence in adolescents and young adults. Eur Psychiatry 2000;15:67-75.

30 Wittchen H-U, Pfister H (eds): DIA-X-Interviews: Manual für Screening-Verfahren und Interview; Interviewheft Längsschnittuntersuchung (DIA-X-12 Monate); Ergänzungsheft (DIA-X-12 Monate); PC-Programm zur Durchführung des Interviews (Längs- und Querschnittuntersuchung); Auswertungsprogramm. Frankfurt, Swets \& Zeitlinger, 1997.

31 World Health Organization: Composite International Diagnostic Interview (CIDI). Geneva, World Health Organization, Division of Mental Health, 1990.

32 American Psychiatric Association: Diagnostic and Statistical Manual of Mental Disorders, ed 4. Washington, APA, 1994

33 World Health Organization: International Classification of Diseases, rev 10. Geneva, World Health Organization, Division of Mental Health, 1994.

34 Wittchen H-U, Lachner G, Wunderlich U, Pfister H: Test-retest reliability of the computerized DSM-IV version of the Munich-Composite International Diagnostic Interview (MCIDI). Soc Psychiatry Psychiatr Epidemiol 1998;33:568-578.
35 Reed V, Gander F, Pfister H, Steiger A, Sonntag $\mathrm{H}$, Trenkwalder C, Hundt W, Wittchen $\mathrm{H}$ $\mathrm{U}$ : To what degree does the Composite International Diagnostic Interview (CIDI) correctly identify DSM-IV disorders? Testing validity issues in a clinical sample. Int $\mathbf{J}$ Methods Psychiatr Res 1998;7:142-155.

36 Lachner G, Wittchen H-U: Das Composite International Diagnostic Interview Substance Abuse Module (CIDI-SAM); in Mann K, Buchkremer G (eds): Sucht: Grundlagen, Diagnostik, Therapie. Stuttgart, Fischer, 1996, pp 147-156.

37 Dlugosch GE, Krieger W: Fragebogen zur Erfassung des Gesundheitsverhaltens. Frankfurt am Main, Swets, 1994.

38 Leigh BC, Stacy AW: Alcohol outcome expectancies: Scale construction and predictive utility in higher order confirmatory models. Psychol Assess 1993;5:216-229.

39 Derogatis LR: SCL-90-R: Self-Report Symptom Inventory. Weinheim, Beltz, 1986.

40 Maier-Diewald W, Wittchen H-U, Hecht H, Werner-Eilert K: Die Münchner Ereignisliste (MEL) - Anwendungsmanual. München, MaxPlanck-Institut für Psychiatrie, Eigendruck, 1983.

41 Lachner G, Wittchen H-U: Skala zum Vergleich von Kompetenzen. München, MaxPlanck-Institut für Psychiatrie, Eigendruck, 1995.

42 Schauder Th: Die Aussagenliste zum Selbstwertgefühl für Kinder und Jugendliche. Weinheim, Beltz, 1991.

43 Perkonigg A, Wittchen H-U: Problemlösekompetenz-Skala: Forschungsversion. München, Max-Planck-Institut für Psychiatrie, Eigendruck, 1995.

44 Reznick JS, Hegeman JM, Kaufman ER, Woods SW, Jacobs M: Retrospective and concurrent self-report of behavioral inhibition and their relation to adult mental health. Dev Psychopathol 1992;4:301-321.

45 Perkonigg A, Wittchen H-U: The Daily-Hassles Scale: Forschungsversion. München, MaxPlanck-Institut für Psychiatrie, Eigendruck, 1995.

46 Schumacher J, Eisemann M, Brähler E: Rückblick auf die Eltern: Der Fragebogen zum erinnerten elterlichen Erziehungsverhalten (FEE). Diagnostica 1999;45:194-204.

47 Bohner G, Hormuth SE, Schwarz N: Die Stimmungsskala: Vorstellung und Validierung einer deutschen Version des 'Mood Survey'. Diagnostica 1991;37:135-148.

48 Harvey PD, Greenberg BR, Serper MR: The affective lability scales: Development, reliability, and validity. J Clin Psychol 1989;45:786793.

49 Wagnild GM, Young HM: Development and psychometric evaluation of the resilience scale. J Nurs Manag 1993;1:165-178.

50 Kuhl J, Fuhrmann A: Selbststeuerungs-Inventar: SSI (Kurzversion). Universität Osnabrück, Vorpublikationsabzug, 1997.

51 Wittchen H-U: Premenstrual Symptom Scale: Forschungsversion. München, Max-Planck-Institut für Psychiatrie, Eigendruck, 1995.
52 Addis ME, Truax P, Jacobson NS: Why do people think they are depressed? The reasons for depression questionnaire. Psychotherapy 1995; 32:476-483.

53 Wunderlich U, Wittchen H-U: Fragebogen zu Selbstmordversuchen. München, Max-PlanckInstitut für Psychiatrie, Eigendruck, 1998.

54 Wittchen H-U: Erleben des ersten Angstanfalls. München, Max-Planck-Institut für Psychiatrie, Eigendruck, 1997.

55 Fydrich T, Renneberg B, Schmitz B, Wittchen H-U: SKID II: Strukturiertes Klinisches Interview für DSM-IV (SKID-II), Achse II: Persönlichkeitsstörungen. Eine deutschsprachige, erweiterte Bearbeitung der amerikanischen Originalversion des SCID-II von First MB, Spitzer RL, Gibbon M, Williams JBW, Benjamin L (Version 3/96). Göttingen, Hogrefe, 1997.

56 Cohen PR: The effects of instruments and informants on ascertainment; in Dunner DL, Gershon ES, Barrett JE (eds): Relatives at risk for mental disorder. New York, Raven Press, 1988, pp 31-52.

57 Andreasen NC, Rice J, Endicott J, Reich T, Coryell W: The family history approach to diagnosis: How useful is it? Arch Gen Psychiatry 1986;43:421-429.

58 Rice JP, Reich Th, Bucholz KK, Neuman RJ, Fishman R, Rochberg N, Hesselbrock VM, Nurnberger JI, Schuckit MA, Begleiter H: Comparison of direct interview and family history diagnoses of alcohol dependence. Alcohol Clin Exp Res 1995;19:1018-1023.

59 Kendler KS, Roy M-A: Validity of a diagnosis of lifetime major depression obtained by personal interview versus family history. Am J Psychiatry 1995; 152:1608-1614.

60 Andreasen NC, Endicott J, Spitzer RL, Winokur G: The family history method using diagnostic criteria: Reliability and validity. Arch Gen Psychiatry 1977;34:229-235.

61 Lieb R, Wittchen H-U, Höfler M, Fuetsch M, Stein M, Merikangas KR: Parental psychopathology, parenting styles and the risk of social phobia in offspring: A prospective-longitudinal community study. Arch Gen Psychiatry 2000; 57:859-866.

62 Lachner G, Wittchen H-U: Münchener Composite International Diagnostic Interview, MCIDI (familiengenetische Version), Elternbefragung, Version 2.0. München, Pax-PlanckInstitut für Psychiatrie, Eigendruck, 1997.

63 Epstein NB, Baldwin LM, Bishop DS: The McMaster Family Assessment Device. J Marriage Fam Ther 1983;9:171-180.

64 Lachner G, Wittchen H-U: Skala elterlicher Erziehungsmassnahmen EMAS-P: Forschungsversion. München, Max-Planck-Institut für Psychiatrie, Eigendruck, 1997.

65 Mattejat F: Subjektive Familienstrukturen. Untersuchungen zur Wahrnehmung der Familienbeziehungen und zu ihrer Bedeutung für die psychische Gesundheit von Jugendlichen. Göttingen, Hogrefe, 1993. 